\title{
РАЗВИТИЕ ПРОФЕСИИОНАЛЬНОГО САМООПРЕДЕЛЕНИЯ ЧЕРЕЗ ИНТЕЛЛЕКТУАЛЬНО-ТВОРЧЕСКУЮ САМОСТОЯТЕЛЬНОСТЬ СТАРШЕКЛАССНИКОВ
}

\section{DEVELOPMENT OF PROFESSIONAL SELF-DETERMINATION THROUGH INTELLECTUAL-CREATIVE SELF-DEFINITION OF HIGH SCHOOLS}

N. Elovikova

T. Holmanskikh

Summary: The article considers pedagogical support as pedagogical conditions: structuring the program of pedagogical support of professional self-determination of high school students; Building their individual route of self-determination in the profession; organization of project research activities in the context of specialized training to prepare high school students for professional self-determination. The formation of intellectual-creative self-reliance of the person enriches the emotional side of the human psyche, forms imagination and creativity, leads to an increase in professional skills.

Keywords: educational support, pedagogical conditions, individual educational route, project activities.
Еловикова Наталья Дмитриевна аспирант, Шадринский государственный педагогический университет, г. Шадринск

rubus72@mail.ru

Холманских Татьяна Дмитриевна

Аспирант, Шадринский государственный педагогический университет, г. Шадринск

Аннотация: В статье рассматривается педагогическое сопровождение в качестве педагогических условий: структурирование программы педагогического сопровождения профессионального самоопределения старшеклассников; построение их индивидуального маршрута самоопределения в профессии; организация проектно-исследовательской деятельности в условиях профильного обучения для подготовки старшеклассников к профессиональному самоопределению. Формирование интеллектуально-творческой самостоятельности личности обогащает эмоциональную сторону психики человека, формирует воображение и креативность, ведет кувеличению профессиональных навыков.

Ключевые слова: педагогическое сопровождение, педагогические условия, индивидуальный образовательный маршрут, проектная деятельность.

\section{Основное соцержание статьи}

Программа педагогического сопровождения обусловлена актуальностью, выраженной условиями модернизации системы российского образования, важнейшей задачей которой является конструирование условий профессионального самоопределения старшеклассников.

Цель программы педагогического сопровождения:

- создание условий, способствующих профессиональному самоопределению старшеклассников;

- формирование знаний и умений, востребованных для адекватного выбора будущей профессии;

- формирование умений планирования своего профессионального пути;

- формирование способности соотносить свои индивидуальные особенности с требованиями выбираемой профессии.

Цель определяет направления программы педагогического сопровождения профессионального самоопределения старшеклассников: 
1) Организация деятельности по получению старшеклассниками знаний о себе, о профессиях: формированию собственной позиции к миру профессий: созданию портфеля достижений; формирование умений планирования адекватного выбора профессии, ориентация на адекватный профессиональный выбор.

В этом направлении содержание сконцентрировано на формировании таких знаниях как: составление плана своего профессионального развития, основываясь на правилах выбора профессий, учитывая свои мотивы, ресурсы личности, интеллектуальные способности и темперамент.

Умения, которые должны приобрести старшеклассники: составлять свой план профессионального развития, при необходимости менять его; подвергать анализу информацию о профессиях, их общих признаках; самосовершенствоваться в учебной и профессиональной деятельности; учитывать при выборе профессии свои индивидуальные психологические и физиологические особенности.

2) Второе условие - разработка индивидуального маршрута профессионального самоопределения.

Встречается разнопрочтимость этого понятия:

- это целенаправленно проектируемая дифференцированная образовательная программа, обеспечивающая учащемуся позиции субъекта выбора, разработки и реализации образовательной программы при осуществлении преподавателями педагогической поддержки его самоопределения и самореализации [2] - это индивидуальная программа, которая составлена для конкретного обучающегося, содержащая конкретные цели, которые необходимо выполнить в установленные сроки.

В нашем исследовании взято во внимание понимание индивидуального образовательного маршрута, которое экстраполировано в рамки педагогического сопровождения профессионального самоопределения старшеклассников.

По мнению ряда педагогов, при построении индивидуального образовательного маршрута содержание образования формируется на основе: личных заказов обучающихся и их родителей; многообразия содержательных аспектов деятельности (теоретического, практического, исследовательского, опытного, познавательного, творческого, производственного, самообразовательного и др.); реализации вариативных, дифференцированных, комплексных образовательных программ [7].

Для нас это индивидуальный маршрут профессио- нального самоопределения, в составе которого сочетание учебной и внеучебной деятельности в целях социальной самореализации личности и формирования обучающимися опыта предпрофессиональной подготовки.

Цель индивидуального маршрута профессионального самоопределения старшеклассников:

- оказание эффективной педагогической поддержки;

- раскрытие перспективы в дальнейшем личностном развитии;

- помощь в определении своих жизненных планов и в соответствии с ними выстроить алгоритм действий;

- обеспечение старшеклассника средствами самопознания, развитие навыков и умений по целеполаганию и планированию;

- формирование мотивов саморазвития, личностного роста.

- содействие пониманию себя как индивидуальности через изучение познавательных интересов, индивидуального стиля деятельности, эмоционально-волевой сферы, характера, темперамента;

- создание условий, способствующих личностному и профессиональному самоопределению обучающихся.

3) Третье условие и направление педагогического сопровождения профессионального самоопределения старшеклассников связано с организацией проектноисследовательской деятельности, ориентированной на профессиональное ориентирование и самоопределение.

Организация проектной деятельности реализуется по двум направлениям: через урочную деятельность при проведении семинаров, практических и лабораторных работ; через внеурочную деятельность при написании учебно-исследовательских, проектных работ, а также при решении олимпиадных конкурсных заданий.

Структурный взгляд на интеллектуальную самостоятельность, как деенаправленное проявление интеллекта рассматривается в виде пространственной структуры, позволяющей отразить различные варианты взаимодействия компонентов [6].

В рамках интеллектуальной самостоятельности выделяются составляющие ее компоненты, обеспечивающие саморазвитие познавательных процессов и индивидуальной познавательной, творческой деятельности: способность прогнозировать ход действий в новых для себя ситуациях; способность оценивать правильность выбранной последовательности действий, способов и средств их реализации; способность анализировать и оценивать результаты деятельности. 
Творческий компонент изучаемого феномена включает в свою структуру:

- активизацию познавательных способностей и творческих сил обучающихся,

- глубокое проникновение в сущность изучаемых вопросов,

- самостоятельность учащихся,

- новизна их суждений и выводов;

- самостоятельный поиск и создание или конструирование какого-то нового продукта (в индивидуальном опыте ученика - нового, неизвестного для него научного знания или метода, но известного, как правило, в общественном опыте) [5].

С этих позиций мы можем сказать, что взаимодействие интеллектуального и творческого компонентов интегрированного данного вида самостоятельности значительно повышает потенциал интеллектуальнотворческой самостоятельности учащихся, выводя её на уровень, необходимый для успешной познавательнотворческой интеллектуальной деятельности.

Существует многообразие современных точек зрения к определению интеллектуально-творческой самостоятельности, когда исследователи выделяют наиболее существенные его черты:

- способность к познанию и решению проблем, которая объединяет все познавательные способности обучающегося;

- способность к осуществлению процесса познания;

- деятельность, направленная на взаимодействие творчества и интеллекта, на развитие оригинальности и уникальности в интеллектуально-творческой самостоятельности.

Творческой называется такая деятельность, которая приводит к получению нового результата, нового продукта. Процесс или результат мыслительного акта называют творческим только в том случае, если он не мог быть получен в результате простого логического вывода или действия по алгоритму. В случае подлинно творческого акта преодолевается логический разрыв на пути от условий задачи к ее решению [2].

Существенно, что в научных изысканиях делается акцент на интеллектуально-творческую инициативу и ее содержательное наполнение. Авторы выделяют в ней креативный компонент как «способность обнаруживать новые решения проблем или обнаружение новых способов выражения; привнесение в жизнь нечто нового для индивида» [3], «особый склад ума, особое качество умственных процессов» [1], «способность к обнаружению и постановке проблем; способность к генерированию большого числа идей; способность продуцировать разнообразные идеи; способность отвечать на раздражители нестандартно; способность усовершенствовать объект, добавляя детали; способность решать проблемы»
[4]. Креативный компонент творческого потенциала с позиции концепции Я.А. Пономарева может рассматриваться как «творческое воображение; богатство, разнообразие идей, ассоциаций; способность быстро переходить от одного способа связи к другому; необычность, самостоятельность, уникальность решения, интуиция, выдумка, предвидение, фантазия» [8].

Выделяя личностный компонент авторы указывают в ней на инициативность и самостоятельность: личностная составляющая творческого потенциала может включать: самостоятельность в выделении и формулировании цели деятельности, наличие мотивации достижения, познавательной мотивации; действия смыслообразования; осознание возможности использования результатов деятельности в профессиональном самоопределении; готовность и способность к саморазвитию и личностному самоопределению; нацеленность на открытие нового и открытость новому, инициативность [9].

Формами организации исследовательской деятельности будут являться:

1. Программы дополнительного образования, реализуемые в индивидуальной и групповой форме, с оформлением результатов исследовательской работы.

2. Применение исследовательского подхода в различных формах деятельности обучающихся при решении индивидуальных исследовательских задач.

3. Курсы по выбору предпрофильной и профильной направленности на основе выполнения исследовательских проектов.

4. Проведение научно-практических конференций и декады проектной деятельности с презентацией интеллектуально-творческого или исследовательского проекта.

\section{Выводы}

Для формирования интеллектуально-творческой самостоятельности необходимы умения и навыки самостоятельной работы, способности преодолевать возникающие затруднения при самостоятельной работе и устойчивое стремление к новому познанию. Все выделенные компоненты взаимосвязаны между собой и их выделение в структуре интеллектуально-творческой самостоятельности отвечает требованиям, предъявляемым к личности современного обучающегося.

Каждое из названных составляющих педагогического сопровождения предполагает активное вовлечение педагогов и школьников в проектную и исследовательскую деятельность, способствует осознанному профессиональному самоопределению старшеклассников, что, в свою очередь, помогает благополучно справиться с учебными задачами, выстроить профессиональную траекторию для успешной самореализации в будущем. 


\section{ЛИТЕРАТУРА}

1. Дружинин В.Н. Психология общих способностей / В.Н. Дружинин. - СПб.: Питер, 2000. — 254с с. 184

2. Лабунская Н.А. Индивидуальный образовательный маршрут студента: подходы к раскрытию понятия/ Н.А. Лабунская. - Текст : непосредственный // Известия Российского государственного педагогического университета им А.И. Герцена, - 2002. - № 3(198). - С. 79-90. - URL: https://www.elibrary.ru/ contents.asp?id=33382409

3. Ожегов С.И., Шведова Н.Ю. Толковый словарь русского языка, Издательство: ИТИ Технологии, 2008 г.- 944 с. с. 75

4. Психология творчества: общая, дифференциальная, прикладная / под ред. Я.А. Пономарева. — М.: Наука, 199. — 345с. с. 133

5. Психология творчества: общая, дифференциальная, прикладная / под ред. Я.А. Пономарева. — М.: Наука, 199. — 345 с., с.165

6. Тряпицына А.П. Организация творческой учебно-познавательной деятельности школьников. - Л., 1989

7. Чеботарева И.И. Индивидуальный образовательный маршрут как способ реализации личностно ориентированного подхода в системе современного образования / И.И. Чеботарева. — Текст: непосредственный // Молодой ученый. — 2020. — № 4 (294). — C. 329-331. — URL: https://moluch.ru/ archive/294/66581/ (дата обращения: 14.02.2021).

8. Черкунова В.И. Творческая инициатива как критерий успешности личностного развития учащегося / В.И. Черкунова. - Текст: непосредственный // Молодой ученый. — 2016. — № 24 (128). — C. 544-547. — URL: https://moluch.ru/archive/128/35378/ (дата обращения: 19.11.2020).

9. Чистякова С.Н., Педагогическая поддержка профессионального самоопределения старшеклассников / С.Н. Чистякова, П.С. Лернер, Н.Ф. Родичев, Е.В. Титов. - М.: Новая школа, 2004; Пряжникова, Е.Ю. Игры и методики для профессионального самоопределения старшеклассников / Е.Ю. Пряжникова. М.: Первое Сентября, 2004; Климов, Г.А. Психология профессионального самоопределения [Текст] / Г.А. Климов. - Ростов-на-Дону: «Феникс», 1996.

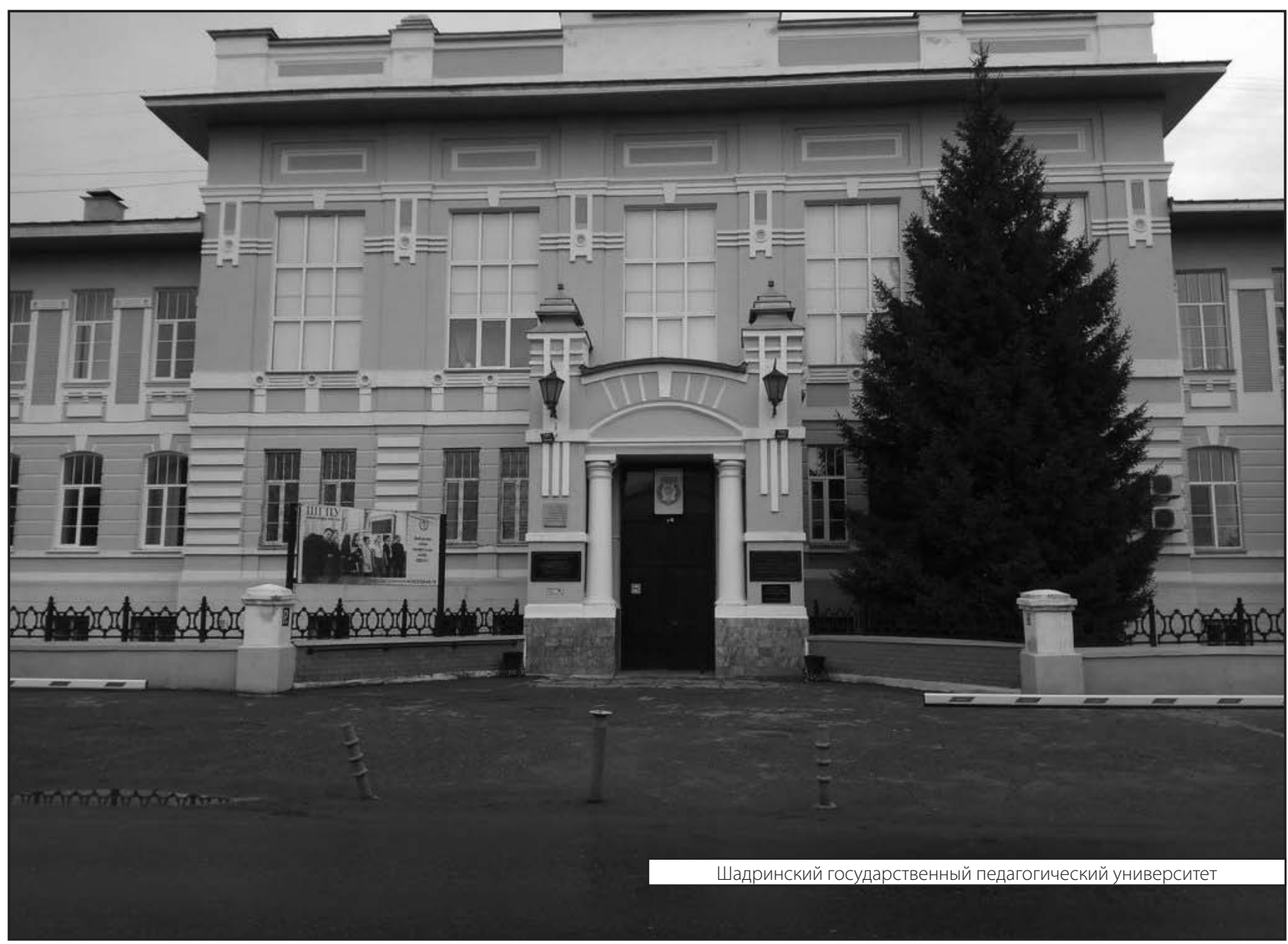

